Article

\title{
Improved Schmidt Conversion of Aldehydes to Nitriles Using Azidotrimethylsilane in 1,1,1,3,3,3-Hexafluoro-2-propanol
}

\author{
Hashim F. Motiwala, Qin Yin and Jeffrey Aubé *
}

Received: 5 November 2015 ; Accepted: 22 December 2015 ; Published: 29 December 2015

Academic Editor: Klaus Banert

Department of Medicinal Chemistry, Delbert M. Shankel Structural Biology Center, University of Kansas, 2034 Becker Drive, West Campus, Lawrence, KS 66047, USA; hashimmotiwala@ku.edu (H.F.M.); qinyin@ku.edu (Q.Y.)

* Correspondence: jaube@unc.edu; Tel.: +1-919-966-9650

\begin{abstract}
The Schmidt reaction of aromatic aldehydes using a substoichiometric amount (40 mol \%) of triflic acid is described. Low catalyst loading was enabled by a strong hydrogen-bond-donating solvent hexafluoro-2-propanol (HFIP). This improved protocol tolerates a broad scope of aldehydes with diverse functional groups and the corresponding nitriles were obtained in good to high yields without the need for aqueous work up.
\end{abstract}

Keywords: Schmidt reaction; aldehydes; nitriles; HFIP

\section{Introduction}

Nitriles are versatile building blocks and precursors to other functionalities such as acids, amines, amides, aldehydes, and tetrazoles. In addition, they are important structural motifs in many natural products [1], pharmaceuticals [2], agrochemicals, and dyes [3-6]. Aromatic nitriles are particularly well-represented in pharmaceutical agents, such as those depicted in Figure 1 [2]. Nitrile groups on the aromatic ring have been viewed as ketone bioisosteres and may increase resistance of aromatic system to the oxidative metabolism [2].
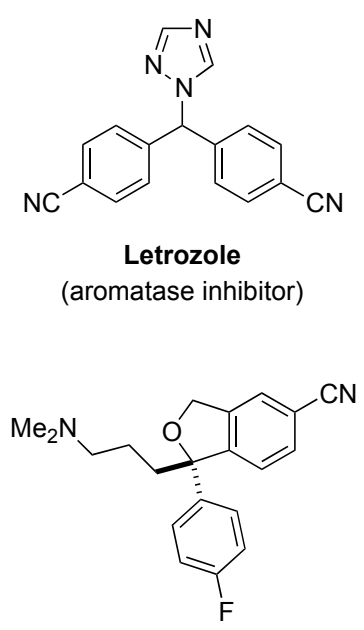

Escitalopram (selective serotonin reuptake inhibitor)<smiles>N#Cc1ccc2c(c1)N(CCCN1CCC(O)CC1)c1ccccc1S2</smiles><smiles>Cc1cc(C)c(Nc2ccnc(Nc3ccc(C#N)cc3)n2)c(C)c1</smiles>

Dapivirine (anti-HIV agent)

Figure 1. Drugs containing aromatic nitriles. 
General strategies for the synthesis of aromatic nitriles include the Sandmeyer reaction of aryldiazonium salts [6-9], Rosenmund-von Braun reaction from aryl halides [9-11], transition metal-catalyzed cyanation of aryl halides [12-15] or direct cyanation through $\mathrm{C}-\mathrm{H}$ bond functionalization of arenes [16-20], and ammoxidation of methyl arenes, which is a preferred industrial process [21-23]. Major drawbacks for most of these processes are the use of stoichiometric to excess amounts of toxic cyanide source, generation of heavy metal waste, requirement of relatively high temperatures (often $>100{ }^{\circ} \mathrm{C}$ ), long reaction times, or the requirement of a reactive aryl halide source (aryl iodides and bromides are generally preferred) [14,24]. Recently, other approaches, such as the dehydration of primary amides [25-28] or aldoximes [29-32], and one pot synthesis from aldehydes [33-43] have gained particular attention in lieu of directly attaching the nitrile group. However, harsh reaction conditions, high temperatures, and functional groups intolerance are some of the problems still associated with these recent methods.

An attractive alternative to the above methods is the Schmidt reaction of aromatic aldehydes with hydrazoic acid as in principle it can deliver the nitriles in one straightforward step [44]. However, historically this reaction has provided a mixture of nitriles and formylanilides (Scheme 1a), thus limiting its utility [45]. Recently, Prabhu and co-workers demonstrated that the Schmidt reaction of aldehydes with sodium azide $\left(\mathrm{NaN}_{3}\right)$ in the presence of triflic acid $(\mathrm{TfOH})$ as a catalyst and acetonitrile $\left(\mathrm{ACN}, \mathrm{CH}_{3} \mathrm{CN}\right.$ ) as solvent exclusively affords the corresponding nitriles (Scheme 1b) [46]. In order to achieve complete conversions, 3 equiv of $\mathrm{TfOH}$ was minimally required for high yields of the aromatic nitriles. For example, only $6 \%$ conversion was observed when 1.5 equiv of $\mathrm{TfOH}$ was used during their optimization studies [46]. Similarly, good results can be obtained using a catalyst in an ionic liquid medium [47]. A one-pot sequential Schmidt/Ritter reactions in the presence of 4 equiv of $\mathrm{HBF}_{4} \cdot \mathrm{OEt}_{2}$ (2 equiv for each reaction) was also reported for the synthesis of $\mathrm{N}$-tert-butylbenzamides from benzaldehydes [48]. We recently reported an efficient substoichiometric catalytic version of another type of Schmidt reaction, specifically the intramolecular Schmidt reaction of ketones with alkyl azides. In that chemistry, using 1,1,1,3,3,3-hexafluoro-2-propanol ( $\left.\mathrm{HFIP},\left(\mathrm{CF}_{3}\right)_{2} \mathrm{CHOH}\right)$ was key to high yields using low loadings of $\mathrm{HCl}$ generated in situ from dissolving acetyl chloride in the solvent [49]. These results prompted us to investigate the strong hydrogen bond donor ability of HFIP in the intermolecular Schmidt reaction of aromatic aldehydes.

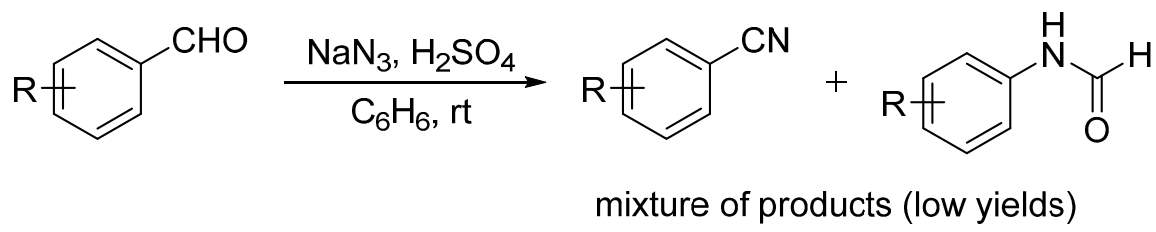

(a)

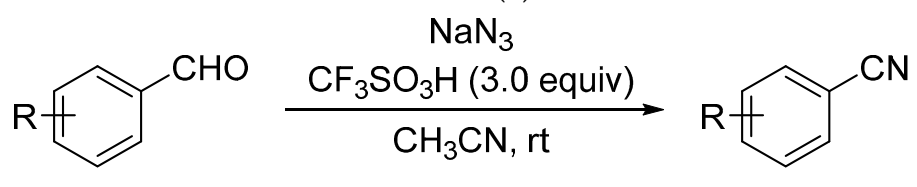

single product (high yields)

(b)

Scheme 1. Schmidt Reactions of Aromatic Aldehydes. (a) Classical Schmidt reaction of aromatic aldehydes (McEwen; [45]); (b) Chemoselective Schmidt reaction of aldehydes to nitriles (Prabhu; [46]).

\section{Results and Discussion}

\subsection{Optimization of Reaction Conditions}

As reported by Prabhu [46], we began our studies on the reaction of 4-nitrobenzaldehyde 1a with $\mathrm{NaN}_{3}$ and $\mathrm{TfOH}$, replacing ACN as reported by Prabhu with HFIP (Table 1, entry 1). Low conversions 
of $2 \mathbf{a}$ with $50 \mathrm{~mol} \% \mathrm{TfOH}$ (entry 1) and $80 \mathrm{~mol} \% \mathrm{AcCl}$ (entry 2) were obtained from these experiments, likely resulting from the low solubility of $\mathrm{NaN}_{3}$ in HFIP. Changing to azidotrimethylsilane $\left(\mathrm{TMSN}_{3}\right)$ as a soluble azide source drastically improved the yield with $25 \mathrm{~mol} \%$ of acid catalysts (entries 3 and 4 ). However, incomplete reactions accompanied by polar byproducts were still observed (TLC) despite long periods of stirring. Both $\mathrm{AcCl}$ and $\mathrm{TiCl}_{4}$ are converted to $\mathrm{HCl}$ when dissolved in HFIP, so the comparable results seen in entries 2 and 3 make sense taking into account the fact that $\mathrm{TiCl}_{4}$ provides fourfold more acid than $\mathrm{AcCl}$. We therefore returned to using triflic acid with $\mathrm{TMSN}_{3}$ as the azide source. Even though the reaction with $30 \mathrm{~mol} \% \mathrm{TfOH}$ offered complete conversion in $2 \mathrm{~h}$, only a modest yield of nitrile was obtained, again with unidentified byproducts (entry 5). Gratifyingly, a 1:1 solvent combination of HFIP and ACN significantly increased the yield but complete conversion was not achieved even after $4 \mathrm{~h}$ (entry 6). Finally, the reaction of $1 \mathrm{a}$ with $40 \mathrm{~mol} \% \mathrm{TfOH}$ in HFIP/ACN (1:1) mixture proved optimal, providing a slightly better yield of $\mathbf{2} \mathbf{a}$ along with a much shorter reaction time (entry 7).

Table 1. Optimization of the Schmidt Reaction of 4-Nitrobenzaldehyde $1 a^{a, b}$.

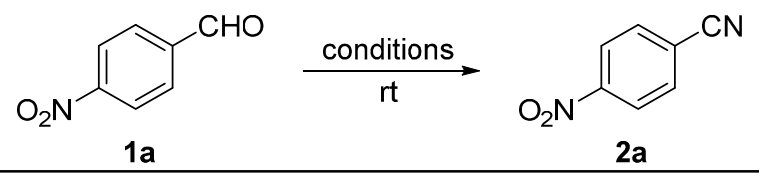

\begin{tabular}{|c|c|c|c|c|c|c|c|c|}
\hline Entry & $\begin{array}{l}\text { Azide } \\
\text { Source }\end{array}$ & $\begin{array}{c}\text { Azide } \\
\text { (equiv) }\end{array}$ & Catalyst & $\begin{array}{l}\text { Catalyst } \\
(\mathrm{mol} \%)\end{array}$ & Solvent & $\begin{array}{c}\text { Time } \\
\text { (h) }\end{array}$ & $\begin{array}{c}\text { NMR Ratio } \\
\text { (2a:1a) }^{c}\end{array}$ & $\begin{array}{c}\text { Yield } \\
(\%)^{d} 2 a\end{array}$ \\
\hline 1 & $\mathrm{NaN}_{3}$ & 1.5 & $\mathrm{CF}_{3} \mathrm{SO}_{3} \mathrm{H}$ & 50 & HFIP & 16 & $30: 70^{\mathrm{e}}$ & ND \\
\hline 2 & $\mathrm{NaN}_{3}$ & 1.5 & $\mathrm{CH}_{3} \mathrm{COCl}^{\mathrm{f}}$ & 80 & HFIP & 8 & $19: 81$ & ND \\
\hline 3 & $\mathrm{TMSN}_{3}$ & 1.5 & $\mathrm{TiCl}_{4} \mathrm{~g}$ & 25 & HFIP & 24 & ND & 75 \\
\hline 4 & $\mathrm{TMSN}_{3}$ & 1.5 & $\mathrm{CF}_{3} \mathrm{SO}_{3} \mathrm{H}$ & 25 & HFIP & 8 & ND & 68 \\
\hline 5 & $\mathrm{TMSN}_{3}$ & 2.0 & $\mathrm{CF}_{3} \mathrm{SO}_{3} \mathrm{H}$ & 30 & HFIP & 2 & ND & $65^{\mathrm{h}}$ \\
\hline 6 & $\mathrm{TMSN}_{3}$ & 2.0 & $\mathrm{CF}_{3} \mathrm{SO}_{3} \mathrm{H}$ & 30 & HFIP / ACN (1:1) & 4 & ND & 81 \\
\hline 7 & $\mathrm{TMSN}_{3}$ & 2.0 & $\mathrm{CF}_{3} \mathrm{SO}_{3} \mathrm{H}$ & 40 & HFIP/ACN (1:1) & $45 \mathrm{~min}$ & ND & 83 \\
\hline
\end{tabular}

a To a solution of 4-nitrobenzaldehyde $1 \mathrm{a}(0.25 \mathrm{or} 0.50 \mathrm{mmol})$ and azide in solvent $(0.50,1.0$, or $2.0 \mathrm{~mL})$ was added a catalyst and the reaction was allowed to stir at $\mathrm{rt}$ for a specified period. ${ }^{\mathrm{b}}$ Concentration of $1 \mathrm{a}$ was $c a$. 0.25 or $0.50 \mathrm{M}$. ${ }^{\mathrm{c}}{ }^{1} \mathrm{H}-\mathrm{NMR}$ ratio was determined on a crude reaction mixture. ${ }^{\mathrm{d}}$ Corrected isolated yield of 2a (2a was contaminated with a small amount $(\mathrm{ca} .3 \%-6 \%)$ of $\mathbf{1 a}) .{ }^{\mathrm{e}}$ Other byproducts were also observed. ${ }^{\mathrm{f}}$ Could generate $80 \mathrm{~mol} \% \mathrm{HCl}$ in situ. ${ }^{\mathrm{g}} \mathrm{A} 1.0 \mathrm{M}$ solution of $\mathrm{TiCl}_{4}$ in $\mathrm{CH}_{2} \mathrm{Cl}_{2}$ was used. ${ }^{\mathrm{h}}{ }^{1} \mathrm{H}-\mathrm{NMR}$ only showed peaks of 2a. ND = Not determined.

\subsection{Substrate Scope}

A series of aromatic aldehydes was examined under the optimized reaction conditions (Table 2). A wide array of functional groups on the aldehydes was well tolerated and the corresponding nitriles were obtained in good to excellent yields. Benzaldehydes containing electron-withdrawing substituents at the para position gave the corresponding nitriles in good yields (entries 1-5). Benzaldehyde 1e required a slightly higher catalyst loading $(60 \mathrm{~mol} \%)$ to achieve a good conversion of the nitrile $2 \mathbf{e}$ (entry 5). Electron-rich substrates with a broad range of functional groups such as hydroxyl, O-allyl, and O-propargyl at the para position underwent facile conversion (entries 6-14). Due to the presence of a basic amine, the substrate with a morpholine substituent needed 1.4 equiv of triflic acid, where 1.0 equiv of acid probably ended up in the amine salt (entry 13). Biphenyl substrate 10 afforded nitrile $2 \mathrm{o}$ in $80 \%$ yield (entry 15). The resulting nitriles were obtained in slightly lower yields for the meta- and ortho-substituted benzaldehydes (entries 16-18). Disubstituted benzaldehydes were also efficiently converted to the desired nitriles in good to high yields (entries 19-25). 2-Naphthonitrile $\mathbf{2 z}$ was readily prepared in $77 \%$ yield from 2-naphthaldehyde $\mathbf{1 z}$ (entry 26). The scope could be extended to heteroaromatic aldehydes affording the representative nitriles in good yields (entries 27 and 28). Throughout, we found that the position of the substituents on the phenyl ring had a relatively minimal influence on the reaction outcome. 
Table 2. Scope of Aromatic Aldehydes ${ }^{a, b}$.

\begin{tabular}{|c|c|c|c|c|c|}
\hline Entry & Aldehyde 1 & Nitrile 2 (\% yield) ${ }^{c}$ & Entry & Aldehyde 1 & Nitrile 2 (\% yield) ${ }^{c}$ \\
\hline 1 & $1 a$ & $\mathbf{2 a}(83 \%)^{d}$ & 17 & $1 q$ & $2 q(70 \%)$ \\
\hline 2 & $1 b$ & 2b $(80 \%)$ & 18 & $1 r$ & $2 r(68 \%)$ \\
\hline 3 & 1c & 2c $(61 \%)$ & 19 & $1 \mathrm{~s}$ & 2 s $(88 \%)$ \\
\hline 4 & $1 d$ & $2 d(78 \%)$ & 20 & $\begin{array}{l}\text { OMe } \\
\mathbf{1 t}\end{array}$ & $\begin{array}{r}\text { OMe } \\
2 t(86 \%)\end{array}$ \\
\hline 5 & $1 e$ & $\begin{array}{l}\text { Me } \\
2 \mathrm{e}(81 \%)^{e}\end{array}$ & 21 & $\begin{array}{l}\text { OMe } \\
1 u\end{array}$ & $\begin{array}{c}\text { OMe } \\
\mathbf{2 u}(89 \%)\end{array}$ \\
\hline 6 & $1 \mathrm{f}$ & $\mathbf{2 f}(95 \%)$ & 22 & $\begin{array}{l}\text { OEt } \\
\mathbf{1 v}\end{array}$ & $\begin{array}{c}\text { OEt } \\
\text { 2v }(91 \%)\end{array}$ \\
\hline 7 & $1 \mathrm{~g}$ & $2 \mathrm{~g}(82 \%)$ & 23 & $\begin{array}{l}\mathrm{NO}_{2} \\
1 \mathrm{w}\end{array}$ & $\begin{array}{c}\mathrm{NO}_{2} \\
2 \mathrm{w}(82 \%)\end{array}$ \\
\hline 8 & $1 \mathrm{~h}$ & $2 h(82 \%)$ & 24 & $1 x$ & $2 \times(54 \%)$ \\
\hline 9 & $1 \mathrm{i}$ & $2 \mathbf{i}(71 \%)$ & 25 & $\begin{array}{l}\mathrm{Br} \\
1 \mathrm{y}\end{array}$ & $\begin{array}{c}\mathrm{Br} \\
2 y(83 \%)\end{array}$ \\
\hline 10 & 1j & $2 \mathrm{j}(90 \%)$ & 26 & $1 z$ & $2 z(77 \%)$ \\
\hline
\end{tabular}


Table 2. Cont.

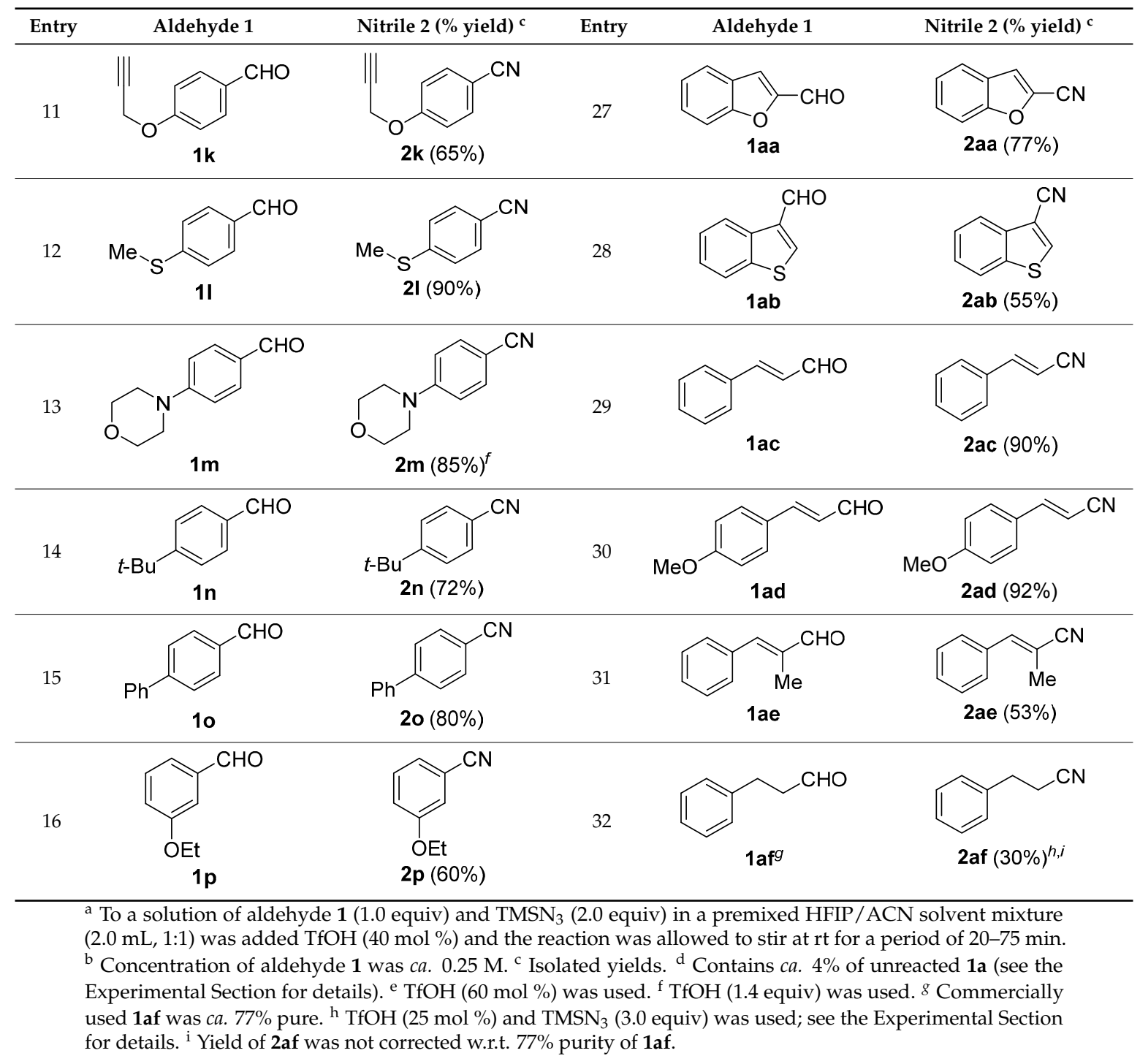

Cinnamaldehydes 1ac and 1ad lacking double bond substitution reacted smoothly to afford the resultant cinnamonitriles in excellent yields (entries 29-30) whereas $\alpha$-methyl substituted cinnamaldehyde 1ae provided the nitrile 2 ae in only $53 \%$ yield (entry 31 ). We would have been pleased if this method were extendable to aliphatic ketones, which have proved problematic in previous methods as well. Unfortunately, reaction of an aliphatic aldehyde, hydrocinnamaldehyde 1af, with 3 equiv of $\mathrm{TMSN}_{3}$ in the presence of $25 \mathrm{~mol} \% \mathrm{TfOH}$ resulted in a complex mixture from which 3-phenylpropionitrile 2af was isolated in low yield (entry 32). Accordingly, additional aliphatic aldehydes were not explored.

This seemingly simple transformation raises a number of interesting mechanistic questions (Scheme 2). Most workers have adopted some variation of the mechanism originally suggested by P. A. S. Smith [50], in which an initially formed azidohydrin adduct $\mathbf{A}$ loses water to afford a pair of equilibrating diazoiminium ions, which can undergo migration of the phenyl group leading to phenylformamide after re-hydration and tautomerization (Scheme $2 b$ ). Alternatively, hydride migration followed by deprotonation would similarly afford nitrile; a variation that involves the same intermediate would entail an E2-style elimination of a proton and nitrogen gas, although this is rarely proposed. Confining oneself to the Smith manifold in Scheme $2 b$, it is hard to justify why a change in solvent would effect the essentially exclusive formation of nitrile since that would most likely be a 
matter of either intrinsic migration potential between a phenyl vs. hydride or differences in the ratio of the acyliminium ion stereoisomers shown in brackets (in general, the barrier for the interconversion between these is thought to be high) [51]. On the other hand, Ostrovskii et al. have suggested that the Smith dehydration mechanism, leading to nitrile, is in competition with a direct rearrangement pathway, leading to phenylformamide (Scheme 2c) [52,53]. Acidic HFIP is a strongly dehydrating medium, which would be consistent with this observation. Finally, it is tempting to speculate that "superelectrophilic" species [54] like the protonated (or hydrogen bonded) diazoiminium ion or nitrilium ions shown in Scheme 2d might also be involved, although this must remain, for the moment, an intriguing conjecture pending further mechanistic work.

(a) Formation of azidohydrin intermediate

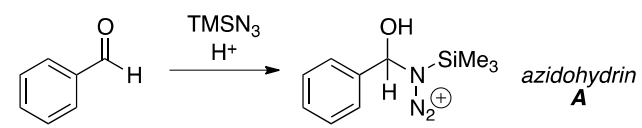

(b) Smith mechanisms leading to formation of phenylformamides vs. nitriles

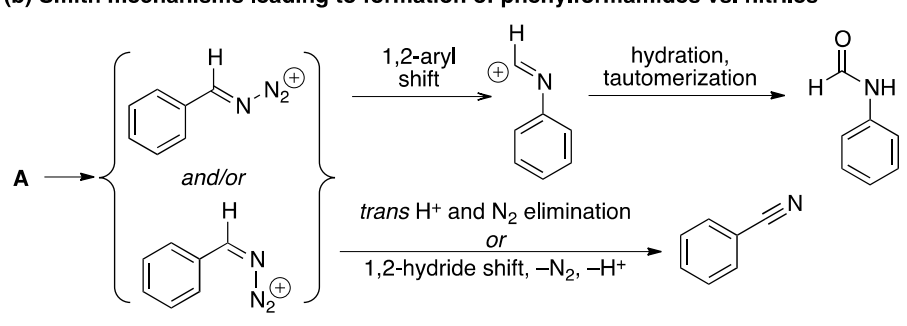

(c) Direct rearrangement route leading to phenylformamide

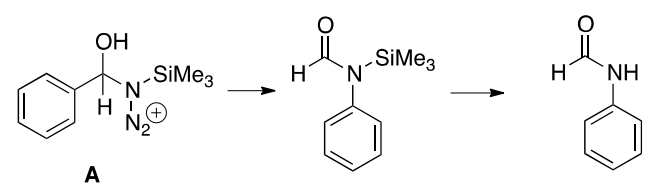

(d) Potential formation of "superelectrophilic" species

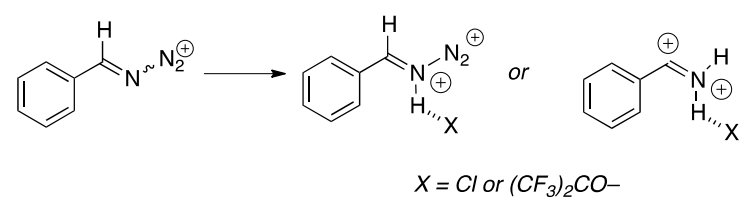

Scheme 2. Mechanistic possibilities. In all cases, the $\mathrm{SiMe}_{3}$ group might be replaced by $\mathrm{H}$ under the reaction conditions (leading to exactly analogous pathways).

\section{Experimental Section}

\subsection{General Information}

Reactions were performed in glass sample vial with rubber lined cap. All chemicals were used as received from commercial source, without further purification. Acetonitrile was dried by passage through neutral alumina columns using a commercial solvent purification system prior to use. Thin-layer chromatography (TLC) was performed using commercial glass-backed silica plates (250 microns) with an organic binder. Visualization was accomplished with UV light. Flash chromatography was carried out on a CombiFlash ${ }^{\circledR}$ purification system using a 4 g normal phase silica flash column. Infrared (IR) spectra were acquired as a solid (Shimadzu FTIR-8400S, Kyoto, Japan). All nuclear magnetic resonance (NMR) spectra $\left({ }^{1} \mathrm{H},{ }^{13} \mathrm{C}, \mathrm{APT}\right)$ were recorded on a $400 \mathrm{MHz}$ instrument (Bruker AV-400, Billerica, MA, USA). NMR spectra were recorded in deuterated chloroform. Chemical shifts are reported in parts per million (ppm) and are referenced to the center line of the solvent $\left(\delta 7.26 \mathrm{ppm}\right.$ for ${ }^{1} \mathrm{H}-\mathrm{NMR}$ and $\delta 77.23$ for ${ }^{13} \mathrm{C}-\mathrm{NMR}$, respectively). Coupling constants are given 
in Hertz (Hz). Melting points were determined on an automated melting point apparatus and are uncorrected. A sample concentrator using $\mathrm{N}_{2}$ gas was used for the concentration of reaction mixtures. Spectroscopic data for the aromatic nitriles prepared according to the methodology described in this paper matched well with those reported in the literature.

\subsection{General Procedure for the Optimization of Reaction Conditions for the Synthesis of 4-Nitrobenzonitrile 2a}

To a solution of 4-nitrobenzaldehyde 1a $\left(0.25\right.$ or $0.50 \mathrm{mmol}, 1.0$ equiv) and $\mathrm{NaN}_{3}$ or $\mathrm{TMSN}_{3}$ (1.5-2.0 equiv) in HFIP or HFIP / ACN mixture (0.50, 1.0, or $2.0 \mathrm{~mL}$ ) was added a catalyst (effervescence due to nitrogen gas evolution was immediately observed). The vial was capped and the reaction mixture was allowed to stir at $\mathrm{rt}$ for a specified period ( $45 \mathrm{~min}$ to $24 \mathrm{~h}$ ). The reaction mixture was concentrated under nitrogen. The residue obtained was diluted with appropriate solvent $\left(\mathrm{CH}_{2} \mathrm{Cl}_{2}\right.$ or EtOAc) and was either filtered through a Pasteur pipette containing a cotton plug to get a crude ${ }^{1} \mathrm{H}-\mathrm{NMR}$ ratio (for entries 1 and 2) or purified using a 4 or $12 \mathrm{~g}$ normal phase silica flash column on a CombiFlash purification system with a gradient elution of $0 \%-10 \%$ EtOAc/hexanes (for entries 3-7). Concentration of the appropriate fractions afforded 4-nitrobenzonitrile $\mathbf{2 a}$ contaminated with a small amount (ca. 3\%-6\%) of 1a (except for entry 5, where pure 2 a was obtained).

\subsection{General Procedure A for the Synthesis of Aromatic Nitriles}

To a solution of an aromatic aldehyde 1 (0.500 mmol, 1.0 equiv) and TMSN 3 (115 mg, $1.00 \mathrm{mmol}$, 2.0 equiv) in a premixed HFIP / ACN mixture $(2.0 \mathrm{~mL}, 1: 1)$ in a nitrogen-flushed two dram vial was added triflic acid (TfOH; $17.7 \mu \mathrm{L}, 0.200 \mathrm{mmol}, 0.40$ equiv) (exotherm and brisk effervescence due to nitrogen gas evolution was immediately observed). The vial was capped and the reaction mixture was allowed to stir at $\mathrm{rt}$ for $20-75 \mathrm{~min}$. The reaction mixture was concentrated under nitrogen. The residue obtained was suspended in $\mathrm{CH}_{2} \mathrm{Cl}_{2}$ /hexanes mixture and loaded on a silica gel in a $5 \mathrm{~g}$ sample cartridge. Purification using a normal phase silica flash column on a CombiFlash purification system afforded a corresponding aromatic nitrile 2 upon concentration of appropriate fractions.

4-Nitrobenzonitrile (2a) [46]: Following the general procedure A, a solution of 4-nitrobenzaldehyde 1a (75.6 mg, 0.500 mmol, 1.0 equiv) and TMSN $_{3}(115 \mathrm{mg}, 1.00 \mathrm{mmol}, 2.0$ equiv) in HFIP/ACN mixture $(2.0 \mathrm{~mL}, 1: 1)$ was treated with $\mathrm{TfOH}(17.7 \mu \mathrm{L}, 0.200 \mathrm{mmol}, 0.40$ equiv). The reaction mixture was stirred at $\mathrm{rt}$ for $45 \mathrm{~min}$. Purification using a $4 \mathrm{~g}$ flash column on a CombiFlash purification system $(0 \%-10 \%$ EtOAc/hexanes over $40 \mathrm{~min}$ ) afforded 2a along with a small amount of unreacted 1 a (eluted between $2.3 \%-4.0 \%$ EtOAc/hexanes) as a colorless crystalline solid (61.6 mg, $0.416 \mathrm{mmol}, 83 \%$ corrected yield; contains $c a .4 \%$ of $\mathbf{1 a}$ as determined by $\left.{ }^{1} \mathrm{H}-\mathrm{NMR}\right)$.

Terephthalonitrile (2b) [55]: Following the general procedure $\mathbf{A}$, a solution of 4-cyanobenzaldehyde $\mathbf{1 b}$ (65.6 mg, $0.500 \mathrm{mmol}, 1.0$ equiv) and TMSN 3 (115 mg, $1.00 \mathrm{mmol}, 2.0$ equiv) in HFIP/ACN mixture $(2.0 \mathrm{~mL}, 1: 1)$ was treated with $\mathrm{TfOH}(17.7 \mu \mathrm{L}, 0.200 \mathrm{mmol}, 0.40$ equiv). The reaction mixture was stirred at $\mathrm{rt}$ for $60 \mathrm{~min}$. Purification using a $4 \mathrm{~g}$ flash column on a CombiFlash purification system $(0 \%-10 \%$ EtOAc/hexanes over $40 \mathrm{~min}$ ) afforded $\mathbf{2 b}$ (eluted between 5.0\%-5.8\% EtOAc/hexanes) as a colorless solid (51.3 mg, $0.400 \mathrm{mmol}, 80 \%$ yield).

4-Chlorobenzonitrile (2c) [46,56]: Following the general procedure A, a solution of 4-chlorobenzaldehyde 1c (70.3 mg, $0.500 \mathrm{mmol}, 1.0$ equiv) and $\mathrm{TMSN}_{3}(115 \mathrm{mg}, 1.00 \mathrm{mmol}, 2.0$ equiv) in HFIP/ACN mixture (2.0 mL, 1:1) was treated with $\mathrm{TfOH}(17.7 \mu \mathrm{L}, 0.200 \mathrm{mmol}, 0.40$ equiv). The reaction mixture was stirred at rt for $45 \mathrm{~min}$. Purification using a $4 \mathrm{~g}$ silica flash column on a CombiFlash purification system (0\%-5\% EtOAc/hexanes over $50 \mathrm{~min}$ ) afforded $2 \mathrm{c}$ (eluted between $0 \%-0.5 \%$ EtOAc/hexanes) as a colorless solid (41.8 $\mathrm{mg}, 0.304 \mathrm{mmol}, 61 \%$ yield).

Methyl 4-cyanobenzoate (2d) [46]: Following the general procedure A, a solution of methyl 4-formylbenzoate $1 \mathrm{~d}(82.1 \mathrm{mg}, 0.500 \mathrm{mmol}, 1.0$ equiv) and TMSN 3 (115 mg, $1.00 \mathrm{mmol}, 2.0$ equiv) in HFIP / ACN mixture $(2.0 \mathrm{~mL}, 1: 1)$ was treated with TfOH $(17.7 \mu \mathrm{L}, 0.200 \mathrm{mmol}, 0.40$ equiv). The reaction 
mixture was stirred at $\mathrm{rt}$ for $30 \mathrm{~min}$. Purification using a $4 \mathrm{~g}$ silica flash column on a CombiFlash purification system ( $0 \%-10 \%$ EtOAc/hexanes over $40 \mathrm{~min}$ ) afforded $2 \mathrm{~d}$ (eluted between $2.5 \%-4.2 \%$ EtOAc/hexanes) as a colorless crystalline solid $(63.0 \mathrm{mg}, 0.391 \mathrm{mmol}, 78 \%$ yield).

4-Methylsulfonylbenzonitrile (2e) [57]: Following a slight modification of the general procedure $\mathbf{A}$, a solution of 4-methylsulfonylbenzaldehyde $1 \mathrm{e}(92.1 \mathrm{mg}, 0.500 \mathrm{mmol}, 1.0$ equiv) and TMSN $3(115 \mathrm{mg}$, $1.00 \mathrm{mmol}, 2.0$ equiv) in HFIP/ ACN mixture $(2.0 \mathrm{~mL}, 1: 1)$ was treated with TfOH $(26.6 \mu \mathrm{L}, 0.300 \mathrm{mmol}$, 0.60 equiv). The reaction mixture was stirred at $\mathrm{rt}$ for $45 \mathrm{~min}$. Purification using a $4 \mathrm{~g}$ silica flash column on a CombiFlash purification system ( $0 \%-40 \%$ EtOAc/hexanes over $40 \mathrm{~min}$ ) afforded $2 \mathbf{e}$ (eluted between 25\%-35\% EtOAc/hexanes) as a colorless solid (72.9 mg, $0.402 \mathrm{mmol}, 81 \%$ yield).

4-Hydroxybenzonitrile (2f) [46]: Following the general procedure $\mathbf{A}$, a solution of 4-hydroxybenzaldehyde 1f $\left(61.1 \mathrm{mg}, 0.500 \mathrm{mmol}, 1.0\right.$ equiv) and $\mathrm{TMSN}_{3}$ (115 mg, $1.00 \mathrm{mmol}$, 2.0 equiv) in HFIP/ACN mixture $(2.0 \mathrm{~mL}, 1: 1)$ was treated with $\mathrm{TfOH}(17.7 \mu \mathrm{L}, 0.200 \mathrm{mmol}, 0.40$ equiv). The reaction mixture was stirred at $\mathrm{rt}$ for $30 \mathrm{~min}$. Purification using a $4 \mathrm{~g}$ silica flash column on a CombiFlash purification system $(0 \%-30 \%$ EtOAc/hexanes over $40 \mathrm{~min}$ ) afforded $\mathbf{2 f}$ (eluted between $15 \%-20 \%$ EtOAc/hexanes) as a colorless crystalline solid (56.5 mg, $0.474 \mathrm{mmol}, 95 \%$ yield).

4-Methoxybenzonitrile (2g) [46]: Following the general procedure $\mathbf{A}$, a solution of $p$-anisaldehyde $\mathbf{1 g}$ (68.1 mg, $0.500 \mathrm{mmol}, 1.0$ equiv) and $\mathrm{TMSN}_{3}(115 \mathrm{mg}, 1.00 \mathrm{mmol}, 2.0$ equiv) in HFIP/ACN mixture ( $2.0 \mathrm{~mL}, 1: 1)$ was treated with $\mathrm{TfOH}(17.7 \mu \mathrm{L}, 0.200 \mathrm{mmol}, 0.40$ equiv). The reaction mixture was stirred at $\mathrm{rt}$ for $30 \mathrm{~min}$. Purification using a $4 \mathrm{~g}$ silica flash column on a CombiFlash purification system ( $0 \%-10 \%$ EtOAc/hexanes over $40 \mathrm{~min}$ ) afforded $2 \mathrm{~g}$ (eluted between $2.3 \%-3.2 \%$ EtOAc/hexanes) as a colorless crystalline solid ( $54.4 \mathrm{mg}, 0.409 \mathrm{mmol}, 82 \%$ yield).

4-Butoxybenzonitrile (2h) [15]: Following the general procedure $\mathbf{A}$, a solution of 4-butoxybenzaldehyde 1h $\left(89.1 \mathrm{mg}, 0.500 \mathrm{mmol}, 1.0\right.$ equiv) and $\mathrm{TMSN}_{3}(115 \mathrm{mg}, 1.00 \mathrm{mmol}, 2.0$ equiv) in HFIP/ACN mixture $(2.0 \mathrm{~mL}, 1: 1)$ was treated with $\mathrm{TfOH}(17.7 \mu \mathrm{L}, 0.200 \mathrm{mmol}, 0.40$ equiv). The reaction mixture was stirred at $\mathrm{rt}$ for $30 \mathrm{~min}$. Purification using a $4 \mathrm{~g}$ silica flash column on a CombiFlash purification system ( $0 \%-5 \%$ EtOAc/hexanes over $40 \mathrm{~min}$ ) afforded $\mathbf{2 h}$ (eluted between $1.1 \%-1.8 \%$ EtOAc/hexanes) as a colorless oil (71.9 mg, $0.410 \mathrm{mmol}, 82 \%$ yield).

4-(Benzyloxy)benzonitrile (2i) [46]: Following the general procedure $\mathbf{A}$, a solution of 4-(benzyloxy)benzaldehyde $1 \mathbf{i}\left(106 \mathrm{mg}, 0.500 \mathrm{mmol}, 1.0\right.$ equiv) and TMSN ${ }_{3}$ (115 mg, $1.00 \mathrm{mmol}$, 2.0 equiv) in HFIP / ACN mixture ( $2.0 \mathrm{~mL}, 1: 1)$ was treated with TfOH ( $17.7 \mu \mathrm{L}, 0.200 \mathrm{mmol}, 0.40$ equiv). The reaction mixture was stirred at $\mathrm{rt}$ for $20 \mathrm{~min}$. Purification using a $4 \mathrm{~g}$ silica flash column on a CombiFlash purification system ( $0 \%-10 \%$ EtOAc/hexanes over $40 \mathrm{~min}$ ) afforded $2 \mathbf{i}$ (eluted between $2.3 \%-3.2 \%$ EtOAc/hexanes) as a colorless crystalline solid $(74.1 \mathrm{mg}, 0.354 \mathrm{mmol}, 71 \%$ yield).

4-(Allyloxy)benzonitrile (2j) [46]: Following the general procedure $\mathbf{A}$, a solution of 4-(allyloxy)benzaldehyde $\mathbf{1 j}$ ( $81.1 \mathrm{mg}, 0.500 \mathrm{mmol}, 1.0$ equiv) and TMSN 3 (115 mg, $1.00 \mathrm{mmol}$, 2.0 equiv) in HFIP / ACN mixture ( $2.0 \mathrm{~mL}, 1: 1)$ was treated with TfOH $(17.7 \mu \mathrm{L}, 0.200 \mathrm{mmol}, 0.40$ equiv). The reaction mixture was stirred at $\mathrm{rt}$ for $45 \mathrm{~min}$. Purification using a $4 \mathrm{~g}$ silica flash column on a CombiFlash purification system ( $0 \%-10 \%$ EtOAc/hexanes over $50 \mathrm{~min}$ ) afforded $\mathbf{2 j}$ (eluted between $3.0 \%-4.0 \%$ EtOAc/hexanes) as a colorless solid (71.4mg, $0.448 \mathrm{mmol}, 90 \%$ yield).

4-(Prop-2-yn-1-yloxy)benzonitrile (2k) [46]: Following the general procedure A, a solution of 4-(prop-2-yn-1-yloxy)benzaldehyde $1 \mathbf{k}\left(80.1 \mathrm{mg}, 0.500 \mathrm{mmol}, 1.0\right.$ equiv) and $\mathrm{TMSN}_{3}$ (115 mg, $1.00 \mathrm{mmol}$, 2.0 equiv) in HFIP/ACN mixture $(2.0 \mathrm{~mL}, 1: 1)$ was treated with $\mathrm{TfOH}(17.7 \mu \mathrm{L}, 0.200 \mathrm{mmol}$, 0.40 equiv). The reaction mixture was stirred at $\mathrm{rt}$ for $30 \mathrm{~min}$. Purification using a $4 \mathrm{~g}$ silica flash column on a CombiFlash purification system ( $0 \%-10 \%$ EtOAc/hexanes over $40 \mathrm{~min}$ ) afforded 2k (eluted between $3.8 \%-5.0 \%$ EtOAc/hexanes) as a colorless solid ( $51.4 \mathrm{mg}, 0.327 \mathrm{mmol}$, $65 \%$ yield). 
4-(Methylthio)benonitrile (2l) [58]: Following the general procedure $\mathbf{A}$, a solution of 4-(methylthio)benzaldehyde 11 ( $76.2 \mathrm{mg}, 0.500 \mathrm{mmol}, 1.0$ equiv) and TMSN 3 (115 mg, $1.00 \mathrm{mmol}$, 2.0 equiv) in HFIP/ ACN mixture ( $2.0 \mathrm{~mL}, 1: 1)$ was treated with $\mathrm{TfOH}(17.7 \mu \mathrm{L}, 0.200 \mathrm{mmol}, 0.40$ equiv). The reaction mixture was stirred at $\mathrm{rt}$ for $30 \mathrm{~min}$. Purification using a $4 \mathrm{~g}$ silica flash column on a CombiFlash purification system $(0 \%-10 \%$ EtOAc/hexanes over $40 \mathrm{~min}$ ) afforded $2 \mathbf{l}$ (eluted between $4.0 \%-4.5 \%$ EtOAc/hexanes) as a colorless solid ( $67.2 \mathrm{mg}, 0.450 \mathrm{mmol}, 90 \%$ yield).

4-(4-Morpholinyl)benzonitrile (2m) [59]: Following the general procedure $\mathbf{A}$, a solution of 4-(4-morpholinyl)benzaldehyde $1 \mathrm{~m}$ ( $95.6 \mathrm{mg}, 0.500 \mathrm{mmol}, 1.0$ equiv) and TMSN 3 (115 mg, $1.00 \mathrm{mmol}$, 2.0 equiv) in HFIP/ ACN mixture ( $2.0 \mathrm{~mL}, 1: 1)$ was treated with $\mathrm{TfOH}(61.9 \mu \mathrm{L}, 0.700 \mathrm{mmol}, 1.40$ equiv). The reaction mixture was stirred at $\mathrm{rt}$ for $60 \mathrm{~min}$. Purification using a $4 \mathrm{~g}$ silica flash column on a CombiFlash purification system $(0 \%-1.5 \% \mathrm{MeOH} / \mathrm{DCM}$ over $40 \mathrm{~min}$ ) afforded $\mathbf{2 m}$ (eluted between $0.4 \%-0.8 \% \mathrm{MeOH} / \mathrm{DCM}$ ) as a light yellow solid (79.8 $\mathrm{mg}, 0.424 \mathrm{mmol}, 85 \%$ yield).

4-tert-Butylbenzonitrile (2n) [56]: Following the general procedure A, a solution of 4-tert-butylbenzaldehyde $1 \mathrm{n}(81.1 \mathrm{mg}, 0.500 \mathrm{mmol}, 1.0$ equiv) and TMSN 3 (115 mg, $1.00 \mathrm{mmol}$, 2.0 equiv) in HFIP / ACN mixture ( $2.0 \mathrm{~mL}, 1: 1)$ was treated with TfOH $(17.7 \mu \mathrm{L}, 0.200 \mathrm{mmol}, 0.40$ equiv). The reaction mixture was stirred at $\mathrm{rt}$ for $30 \mathrm{~min}$. Purification using a $4 \mathrm{~g}$ silica flash column on a CombiFlash purification system ( $0 \%-10 \%$ EtOAc/hexanes over $40 \mathrm{~min}$ ) afforded $\mathbf{2 n}$ (eluted between $0 \%-1 \%$ EtOAc/hexanes) as a yellow oil ( $56.9 \mathrm{mg}, 0.357 \mathrm{mmol}, 72 \%$ yield).

Biphenyl-4-carbonitrile (2o) [46]: Following the general procedure $\mathbf{A}$, a solution of biphenyl-4-carboxaldehyde 10 (91.1 mg, $0.500 \mathrm{mmol}, 1.0$ equiv) and $\mathrm{TMSN}_{3}(115 \mathrm{mg}, 1.00 \mathrm{mmol}$, 2.0 equiv) in HFIP and ACN mixture $(2.0 \mathrm{~mL}, 1: 1)$ was treated with $\mathrm{TfOH}(17.7 \mu \mathrm{L}, 0.200 \mathrm{mmol}$, 0.40 equiv). The reaction mixture was stirred at $\mathrm{rt}$ for $45 \mathrm{~min}$. Purification using a $4 \mathrm{~g}$ silica flash column on a CombiFlash purification system $(0 \%-5 \%$ EtOAc/hexanes over $50 \mathrm{~min})$ afforded 20 (eluted between $0 \%-1.5 \%$ EtOAc/hexanes) as an off-white solid (71.4 mg, $0.398 \mathrm{mmol}, 80 \%$ yield).

3-Ethoxybenzonitrile (2p) [55]: Following the general procedure $\mathbf{A}$, a solution of 3-ethoxybenzaldehyde $1 \mathbf{p}\left(75.1 \mathrm{mg}, 0.500 \mathrm{mmol}, 1.0\right.$ equiv) and $\mathrm{TMSN}_{3}(115 \mathrm{mg}, 1.00 \mathrm{mmol}, 2.0$ equiv) in HFIP/ACN mixture $(2.0 \mathrm{~mL}, 1: 1)$ was treated with $\mathrm{TfOH}(17.7 \mu \mathrm{L}, 0.200 \mathrm{mmol}, 0.40$ equiv). The reaction mixture was stirred at $\mathrm{rt}$ for $60 \mathrm{~min}$. Purification using a $4 \mathrm{~g}$ silica flash column on a CombiFlash purification system ( $0 \%-5 \%$ EtOAc/hexanes over $50 \mathrm{~min}$ ) afforded $2 \mathbf{p}$ (eluted between $1.2 \%-1.5 \%$ EtOAc/hexanes) as a colorless oil (44.0 mg, $0.299 \mathrm{mmol}, 60 \%$ yield).

2-Methoxybenzonitrile (2q) [55]: Following the general procedure $\mathbf{A}$, a solution of $o$-anisaldehyde $\mathbf{1 q}$ (68.1 mg, $0.500 \mathrm{mmol}, 1.0$ equiv) and TMSN $3(115 \mathrm{mg}, 1.00 \mathrm{mmol}, 2.0$ equiv) in HFIP/ ACN mixture $(2.0 \mathrm{~mL}, 1: 1)$ was treated with $\mathrm{TfOH}(17.7 \mu \mathrm{L}, 0.200 \mathrm{mmol}, 0.40$ equiv). The reaction mixture was stirred at $\mathrm{rt}$ for $60 \mathrm{~min}$. Purification using a $4 \mathrm{~g}$ silica flash column on a CombiFlash purification system ( $0 \%-10 \%$ EtOAc/hexanes over $40 \mathrm{~min}$ ) afforded $\mathbf{2 q}$ (eluted between $2.5 \%-5.0 \%$ EtOAc/hexanes) as a colorless oil ( $46.4 \mathrm{mg}, 0.348 \mathrm{mmol}, 70 \%$ yield).

2-Bromobenzonitrile (2r) [46]: Following the general procedure A, a solution of 2-bromobenzaldehyde 1r ( $92.5 \mathrm{mg}, 0.500 \mathrm{mmol}, 1.0$ equiv) and TMSN 3 (115 mg, $1.00 \mathrm{mmol}, 2.0$ equiv) in HFIP/ACN mixture $(2.0 \mathrm{~mL}, 1: 1)$ was treated with $\mathrm{TfOH}(17.7 \mu \mathrm{L}, 0.200 \mathrm{mmol}, 0.40$ equiv). The reaction mixture was stirred at $\mathrm{rt}$ for $30 \mathrm{~min}$. Purification using a $4 \mathrm{~g}$ silica flash column on a CombiFlash purification system (0\%-10\% EtOAc/hexanes over $40 \mathrm{~min}$ ) afforded $2 \mathrm{r}$ (eluted between $2.0 \%-2.5 \%$ EtOAc/hexanes) as a colorless crystalline solid ( $61.7 \mathrm{mg}, 0.339 \mathrm{mmol}, 68 \%$ yield).

1,3-Benzodioxole-5-carbonitrile (2s) [46]: Following the general procedure A, a solution of piperonal 1s (75.1 mg, $0.500 \mathrm{mmol}, 1.0$ equiv) and TMSN 3 (115 mg, $1.00 \mathrm{mmol}, 2.0$ equiv) in HFIP/ACN mixture $(2.0 \mathrm{~mL}, 1: 1)$ was treated with $\mathrm{TfOH}(17.7 \mu \mathrm{L}, 0.200 \mathrm{mmol}, 0.40$ equiv). The reaction mixture was stirred at $\mathrm{rt}$ for $60 \mathrm{~min}$. Purification using a $4 \mathrm{~g}$ silica flash column on a CombiFlash purification system 
(0\%-25\% EtOAc/hexanes over $40 \mathrm{~min}$ ) afforded $2 \mathrm{~s}$ (eluted between $3.8 \%-5.6 \%$ EtOAc/hexanes) as a colorless solid ( $64.8 \mathrm{mg}, 0.441 \mathrm{mmol}, 88 \%$ ).

3,4-Dimethoxybenzonitrile (2t) [46]: Following the general procedure $\mathbf{A}$, a solution of 3,4-dimethoxybenzaldehyde 1t $(83.1 \mathrm{mg}, 0.500 \mathrm{mmol}, 1.0$ equiv) and TMSN 3 (115 mg, $1.00 \mathrm{mmol}$, 2.0 equiv) in HFIP/ ACN mixture ( $2.0 \mathrm{~mL}, 1: 1)$ was treated with TfOH $(17.7 \mu \mathrm{L}, 0.200 \mathrm{mmol}, 0.40$ equiv). The reaction mixture was stirred at $\mathrm{rt}$ for $20 \mathrm{~min}$. Purification using a $4 \mathrm{~g}$ silica flash column on a CombiFlash purification system ( $0 \%-30 \%$ EtOAc/hexanes over $40 \mathrm{~min}$ ) afforded $\mathbf{2 t}$ (eluted between $11 \%-16 \%$ EtOAc/hexanes) as a colorless crystalline solid (70.0 mg, $0.429 \mathrm{mmol}, 86 \%$ yield).

4-Hydroxy-3-methoxybenzonitrile (2u) [60,61]: Following the general procedure $\mathbf{A}$, a solution of 4-hydroxy-3-methoxybenzaldehyde (vanillin) $1 \mathbf{u}\left(76.1 \mathrm{mg}, 0.500 \mathrm{mmol}, 1.0\right.$ equiv) and $\mathrm{TMSN}_{3}(115 \mathrm{mg}$, $1.00 \mathrm{mmol}, 2.0$ equiv) in HFIP / ACN mixture $(2.0 \mathrm{~mL}, 1: 1)$ was treated with TfOH $(17.7 \mu \mathrm{L}, 0.200 \mathrm{mmol}$, 0.40 equiv). The reaction mixture was stirred at $\mathrm{rt}$ for $30 \mathrm{~min}$. Purification using a $4 \mathrm{~g}$ silica flash column on a CombiFlash purification system ( $0 \%-25 \%$ EtOAc/hexanes over $50 \mathrm{~min})$ afforded $2 \mathbf{u}$ (eluted between 12.5\%-16\% EtOAc/hexanes) as a colorless crystalline solid ( $66.5 \mathrm{mg}, 0.446 \mathrm{mmol}$, $89 \%$ yield).

3-Ethoxy-4-hydroxybenzonitrile (2v) [62]: Following the general procedure A, a solution of 3-ethoxy-4-hydroxybenzaldehyde $1 \mathbf{v}\left(83.1 \mathrm{mg}, 0.500 \mathrm{mmol}, 1.0\right.$ equiv) and TMSN $\mathrm{T}_{3}(115 \mathrm{mg}, 1.00 \mathrm{mmol}$, 2.0 equiv) in HFIP/ACN mixture ( $2.0 \mathrm{~mL}, 1: 1)$ was treated with $\mathrm{TfOH}(17.7 \mu \mathrm{L}, 0.200 \mathrm{mmol}, 0.40$ equiv). The reaction mixture was stirred at $\mathrm{rt}$ for $75 \mathrm{~min}$. Purification using a $4 \mathrm{~g}$ silica flash column on a CombiFlash purification system $(0 \%-25 \%$ EtOAc/hexanes over $40 \mathrm{~min}$ ) afforded $2 \mathbf{v}$ (eluted between $8.1 \%-12.5 \%$ EtOAc/hexanes) as a colorless solid ( $74.3 \mathrm{mg}, 0.455 \mathrm{mmol}, 91 \%$ yield).

4-Hydroxy-3-nitrobenzonitrile (2w) [46]: Following the general procedure $\mathbf{A}$, a solution of 4-hydroxy-3-nitrobenzaldehyde $\mathbf{1 w}\left(83.6 \mathrm{mg}, 0.500 \mathrm{mmol}, 1.0\right.$ equiv) and $\mathrm{TMSN}_{3}$ (115 mg, $1.00 \mathrm{mmol}$, 2.0 equiv) in HFIP/ ACN mixture ( $2.0 \mathrm{~mL}, 1: 1)$ was treated with $\mathrm{TfOH}(17.7 \mu \mathrm{L}, 0.200 \mathrm{mmol}, 0.40$ equiv). The reaction mixture was stirred at $\mathrm{rt}$ for $45 \mathrm{~min}$. Purification using a $4 \mathrm{~g}$ silica flash column on a CombiFlash purification system $(0 \%-20 \%$ EtOAc/hexanes over $40 \mathrm{~min}$ ) afforded $\mathbf{2 w}$ (eluted between $6.5 \%-9 \%$ EtOAc/hexanes) as a yellow solid $(67.7 \mathrm{mg}, 0.413 \mathrm{mmol}, 82 \%$ yield $)$.

4-Hydroxy-(1,1-biphenyl)-3-carbonitrile (2x) [46]: Following the general procedure A, a solution of 4-hydroxy-(1,1-biphenyl)-3-carbaldehyde $\mathbf{1 x}\left(99.1 \mathrm{mg}, 0.500 \mathrm{mmol}, 1.0\right.$ equiv) and $\mathrm{TMSN}_{3}(115 \mathrm{mg}$, $1.00 \mathrm{mmol}, 2.0$ equiv) in HFIP / ACN mixture $(2.0 \mathrm{~mL}, 1: 1)$ was treated with TfOH $(17.7 \mu \mathrm{L}, 0.200 \mathrm{mmol}$, 0.40 equiv). The reaction mixture was stirred at $\mathrm{rt}$ for $20 \mathrm{~min}$. Purification using a $4 \mathrm{~g}$ silica flash column on a CombiFlash purification system $(0 \%-5 \%$ EtOAc/hexanes over $40 \mathrm{~min}$ ) afforded $2 \mathbf{x}$ (eluted between $1.0 \%-2.0 \%$ EtOAc/hexanes) as a yellow solid ( $52.5 \mathrm{mg}, 0.269 \mathrm{mmol}, 54 \%$ yield).

3,4-Dibromobenzonitrile (2y) [63]: Following the general procedure A, a solution of 3,4-dibromobenzaldehyde $1 \mathbf{y}$ (132 mg, $0.500 \mathrm{mmol}, 1.0$ equiv) and $\mathrm{TMSN}_{3}(115 \mathrm{mg}, 1.00 \mathrm{mmol}$, 2.0 equiv) in HFIP / ACN mixture ( $2.0 \mathrm{~mL}, 1: 1)$ was treated with TfOH $(17.7 \mu \mathrm{L}, 0.200 \mathrm{mmol}, 0.40$ equiv). The reaction mixture was stirred at $\mathrm{rt}$ for $45 \mathrm{~min}$. Purification using a $4 \mathrm{~g}$ silica flash column on a CombiFlash purification system (100\% hexanes over $5 \mathrm{~min}$ ) afforded $\mathbf{2 y}$ as a colorless solid $(108 \mathrm{mg}$, $0.414 \mathrm{mmol}, 83 \%$ yield). Mp: $118-120^{\circ} \mathrm{C}$; TLC (10\% EtOAc/hexanes): $\mathrm{R}_{f}=0.55$; IR (neat) $2227 \mathrm{~cm}^{-1}$; ${ }^{1} \mathrm{H}-\mathrm{NMR}\left(400 \mathrm{MHz}, \mathrm{CDCl}_{3}\right) \delta 7.88(\mathrm{~d}, J=1.9 \mathrm{~Hz}, 1 \mathrm{H}), 7.74(\mathrm{~d}, J=8.3 \mathrm{~Hz}, 1 \mathrm{H}), 7.44(\mathrm{dd}, J=8.3,1.9 \mathrm{~Hz}$, $1 \mathrm{H}) ;{ }^{13} \mathrm{C}-\mathrm{NMR}\left(101 \mathrm{MHz}, \mathrm{CDCl}_{3}\right) \delta 136.8,134.7,131.6,131.0,126.1,116.8,112.9$. Compound $2 \mathrm{y}$ did not afford a good parent ion in MS.

2-Naphthonitrile (2z) [55]: Following the general procedure $\mathbf{A}$, a solution of 2-naphthaldehyde $\mathbf{1 z}$ (78.1 $\mathrm{mg}, 0.500 \mathrm{mmol}, 1.0$ equiv) and $\mathrm{TMSN}_{3}$ (115 mg, $1.00 \mathrm{mmol}, 2.0$ equiv) in HFIP/ ACN mixture (2.0 $\mathrm{mL}, 1: 1)$ was treated with $\mathrm{TfOH}(17.7 \mu \mathrm{L}, 0.200 \mathrm{mmol}, 0.40$ equiv). The reaction mixture was stirred at $\mathrm{rt}$ for $60 \mathrm{~min}$. Purification using a $4 \mathrm{~g}$ silica flash column on a CombiFlash purification system 
( $0 \%-10 \%$ EtOAc/hexanes over $50 \mathrm{~min}$ ) afforded $2 \mathbf{z}$ (eluted between $0.1 \%-0.4 \%$ EtOAc/hexanes) as a light yellow solid $(59.0 \mathrm{mg}, 0.385 \mathrm{mmol}, 77 \%$ yield).

Benzofuran-2-carbonitrile (2aa) [64]: Following the general procedure A, a solution of 2-benzofurancarboxaldehyde 1aa (73.1 mg, $0.500 \mathrm{mmol}, 1.0$ equiv) and $\mathrm{TMSN}_{3}$ (115 mg, $1.00 \mathrm{mmol}$, 2.0 equiv) in HFIP/ ACN mixture ( $2.0 \mathrm{~mL}, 1: 1)$ was treated with $\mathrm{TfOH}(17.7 \mu \mathrm{L}, 0.200 \mathrm{mmol}, 0.40$ equiv). The reaction mixture was stirred at $\mathrm{rt}$ for $20 \mathrm{~min}$. Purification using a $4 \mathrm{~g}$ silica flash column on a CombiFlash purification system ( $0 \%-10 \%$ EtOAc/hexanes over $40 \mathrm{~min}$ ) afforded 2aa (eluted between $0.5 \%-1.8 \%$ EtOAc/hexanes) as a yellow solid ( $55.2 \mathrm{mg}, 0.386 \mathrm{mmol}, 77 \%$ yield).

Benzo[b]thiophene-3-carbonitrile (2ab) [65]: Following the general procedure $\mathbf{A}$, a solution of thianaphthene-3-carboxaldehyde $1 \mathbf{a b}\left(81.1 \mathrm{mg}, 0.500 \mathrm{mmol}, 1.0\right.$ equiv) and TMSN $\mathrm{T}_{3}(115 \mathrm{mg}, 1.00 \mathrm{mmol}$, 2.0 equiv) in HFIP/ ACN mixture ( $2.0 \mathrm{~mL}, 1: 1)$ was treated with $\mathrm{TfOH}(17.7 \mu \mathrm{L}, 0.200 \mathrm{mmol}, 0.40$ equiv). The reaction mixture was stirred at $\mathrm{rt}$ for $20 \mathrm{~min}$. Purification using a $4 \mathrm{~g}$ silica flash column on a CombiFlash purification system $(0 \%-5 \%$ EtOAc/hexanes over $50 \mathrm{~min})$ afforded $2 \mathbf{a b}$ (eluted between $0.4 \%-0.9 \% \mathrm{EtOAc} /$ hexanes) as a colorless crystalline solid ( $43.8 \mathrm{mg}, 0.275 \mathrm{mmol}, 55 \%$ yield).

Cinnamonitrile (2ac) [46]: Following the general procedure A, a solution of trans-cinnamaldehyde 1ac (66.1 mg, $0.500 \mathrm{mmol}, 1.0$ equiv) and TMSN 3 (115 mg, $1.00 \mathrm{mmol}, 2.0$ equiv) in HFIP/ ACN mixture $(2.0 \mathrm{~mL}, 1: 1)$ was treated with $\mathrm{TfOH}(17.7 \mu \mathrm{L}, 0.200 \mathrm{mmol}, 0.40$ equiv). The reaction mixture was stirred at $\mathrm{rt}$ for $45 \mathrm{~min}$. Purification using a $4 \mathrm{~g}$ silica flash column on a CombiFlash purification system ( $0 \%-10 \%$ EtOAc/hexanes over $40 \mathrm{~min}$ ) afforded 2 ac (eluted between $2.3 \%-2.8 \%$ EtOAc/hexanes) as a colorless oil ( $58.0 \mathrm{mg}, 0.449 \mathrm{mmol}, 90 \%$ yield).

(E)-3-(4-Methoxyphenyl)acrylonitrile (2ad) [66]: Following the general procedure $\mathbf{A}$, a solution of 4-methoxycinnamaldehyde 1ad ( $81.1 \mathrm{mg}, 0.500 \mathrm{mmol}, 1.0$ equiv) and TMSN ${ }_{3}(115 \mathrm{mg}, 1.00 \mathrm{mmol}$, 2.0 equiv) in HFIP / ACN mixture (2.0 mL, 1:1) was treated with TfOH $(17.7 \mu \mathrm{L}, 0.200 \mathrm{mmol}, 0.40$ equiv). The reaction mixture was stirred at $\mathrm{rt}$ for $20 \mathrm{~min}$. Purification using a $4 \mathrm{~g}$ silica flash column on a CombiFlash purification system ( $0 \%-10 \%$ EtOAc/hexanes over $40 \mathrm{~min}$ ) afforded 2ad (eluted between $4.3 \%-5.5 \%$ EtOAc/hexanes) as a colorless solid (73.1 $\mathrm{mg}, 0.459 \mathrm{mmol}, 92 \%$ yield).

$\alpha$-Methyl-trans-cinnamonitrile (2ae) [67,68]: Following the general procedure A, a solution of $\alpha$-methyl-trans-cinnamaldehyde 1 ae $(73.1 \mathrm{mg}, 0.500 \mathrm{mmol}, 1.0$ equiv) and TMSN 3 (115 mg, $1.00 \mathrm{mmol}$, 2.0 equiv) in HFIP / ACN mixture (2.0 mL, 1:1) was treated with TfOH (17.7 $\mu \mathrm{L}, 0.200 \mathrm{mmol}, 0.40$ equiv). The reaction mixture was stirred at rt for $45 \mathrm{~min}$. Purification using a $12 \mathrm{~g}$ silica flash column on a CombiFlash purification system ( $0 \%-5 \%$ EtOAc/hexanes over $50 \mathrm{~min}$ ) afforded 2ae (eluted between $0.5 \%-1.5 \%$ EtOAc/hexanes) as a pale yellow oil ( $38.0 \mathrm{mg}, 0.265 \mathrm{mmol}, 53 \%$ yield).

3-Phenylpropionitrile (2af) [69,70]: Following a slight modification of the general procedure A, a solution of $c a$. $77 \%$ pure hydrocinnamaldehyde 1 af $(26.8 \mathrm{mg}, 0.200 \mathrm{mmol}, 1.0$ equiv; uncorrected for impurities) and $\mathrm{TMSN}_{3}(69.1 \mathrm{mg}, 0.600 \mathrm{mmol}, 3.0$ equiv) in HFIP/ACN mixture $(1.0 \mathrm{~mL}, 1: 1)$ was treated with $\mathrm{TfOH}(4.43 \mu \mathrm{L}, 0.0500 \mathrm{mmol}, 0.25$ equiv). The reaction mixture was stirred at $\mathrm{rt}$ for $60 \mathrm{~min}$. Purification using a $4 \mathrm{~g}$ silica flash column on a CombiFlash purification system $(0 \%-5 \%$ EtOAc/hexanes over $40 \mathrm{~min}$ ) afforded 2af (eluted between 2.8-3.4\% EtOAc/hexanes) as a colorless oil ( $8.00 \mathrm{mg}, 0.0610 \mathrm{mmol}$, $30 \%$ uncorrected yield and $c a .40 \%$ corrected yield w.r.t. $77 \%$ purity of $\mathbf{1 a f}$ ).

Acknowledgments: This work was supported by the University of Kansas.

Author Contributions: H.F.M. and J.A. conceived the study, H.F.M. and Q.Y. did the experiments and interpreted the primary data, H.F.M. and J.A. wrote the paper, and all authors read, edited, and approved the manuscript prior to submission.

Conflicts of Interest: The authors declare no conflict of interest.

\section{References}

1. Fleming, F.F. Nitrile-containing natural products. Nat. Prod. Rep. 1999, 16, 597-606. [CrossRef] 
2. Fleming, F.F.; Yao, L.; Ravikumar, P.C.; Funk, L.; Shook, B.C. Nitrile-containing pharmaceuticals: Efficacious roles of the nitrile pharmacophore. J. Med. Chem. 2010, 53, 7902-7917. [CrossRef] [PubMed]

3. Fatiadi, A.J. Preparation and synthetic applications of cyano compounds. In Triple-Bonded Functional Groups; John Wiley \& Sons, Ltd.: Chichester, UK, 1983; Volume 2, pp. 1057-1303.

4. Larock, R.C. Comprehensive Organic Transformations; Wiley-VCH: New York, NY, USA, 1989.

5. Kleemann, A.; Engel, J.; Kutscher, B.; Reichert, D. Pharmaceutical Substances: Syntheses, Patents, Applications, 4th ed.; Georg Thieme: Stuttgart, Germany, 2001.

6. Smith, M.B.; March, J. March's Advanced Organic Chemistry: Reactions, Mechanisms, and Structure, 6th ed.; Wiley: Hoboken, NJ, USA, 2007; p. 2374.

7. Sandmeyer, T. Substitution of the amido-group in aromatic derivatives by chlorine, bromine, and cyanogen. Chem. Ber. 1884, 17, 2650-2653. [CrossRef]

8. Sandmeyer, T. Ueberführung der drei nitraniline in die nitrobenzoësäuren. Chem. Ber. 1885, 18, $1492-1496$. [CrossRef]

9. Mowry, D.T. The preparation of nitriles. Chem. Rev. 1948, 42, 189-283. [CrossRef] [PubMed]

10. Rosenmund, K.W.; Struck, E. Halogen attached to a ring carbon atom and its replacement by other substituents. I. Replacement of the halogen by the carboxyl group. Chem. Ber. 1919, 52, 1749-1756. [CrossRef]

11. V. Braun, J.; Manz, G. Fluoranthen und seine derivate. III. Mitteilung. Justus Liebigs Ann. Chem. 1931, 488, 111-126. [CrossRef]

12. Takagi, K.; Okamoto, T.; Sakakibara, Y.; Oka, S. Palladium(II) catalyzed synthesis of aryl cyanides from aryl halides. Chem. Lett. 1973, 2, 471-474. [CrossRef]

13. Ellis, G.P.; Romney-Alexander, T.M. Cyanation of aromatic halides. Chem. Rev. 1987, 87, 779-794. [CrossRef]

14. Anbarasan, P.; Schareina, T.; Beller, M. Recent developments and perspectives in palladium-catalyzed cyanation of aryl halides: Synthesis of benzonitriles. Chem. Soc. Rev. 2011, 40, 5049-5067. [CrossRef] [PubMed]

15. Wen, Q.; Jin, J.; Mei, Y.; Lu, P.; Wang, Y. Copper-mediated cyanation of aryl halides by activation of benzyl Cyanide as the cyanide source. Eur. J. Org. Chem. 2013, 2013, 4032-4036. [CrossRef]

16. Kim, J.; Chang, S. A new combined source of "CN" from $\mathrm{N}, \mathrm{N}$-dimethylformamide and ammonia in the palladium-catalyzed cyanation of aryl C-H bonds. J. Am. Chem. Soc. 2010, 132, 10272-10274. [CrossRef] [PubMed]

17. Yan, G.; Kuang, C.; Zhang, Y.; Wang, J. Palladium-catalyzed direct cyanation of indoles with $\mathrm{K}_{4}\left[\mathrm{Fe}(\mathrm{CN})_{6}\right]$. Org. Lett. 2010, 12, 1052-1055. [CrossRef] [PubMed]

18. Do, H.-Q.; Daugulis, O. Copper-catalyzed cyanation of heterocycle carbon-hydrogen bonds. Org. Lett. 2010, 12, 2517-2519. [CrossRef] [PubMed]

19. Yang, Y.; Zhang, Y.; Wang, J. Lewis acid catalyzed direct cyanation of indoles and pyrroles with $N$-cyano-N-phenyl-p-toluenesulfonamide (NCTS). Org. Lett. 2011, 13, 5608-5611. [CrossRef] [PubMed]

20. Ding, S.; Jiao, N. Direct transformation of $N, N$-dimethylformamide to $-\mathrm{CN}$ : Pd-catalyzed cyanation of heteroarenes via C-H functionalization. J. Am. Chem. Soc. 2011, 133, 12374-12377. [CrossRef] [PubMed]

21. Pollak, P.; Romeder, G.; Hagedorn, F.; Gelbke, H.-P. Nitriles. In Ullmann's Encyclopedia of Industrial Chemistry; Wiley-VCH: Weinheim, Germany, 2000.

22. Lücke, B.; Martin, A. Fine Chemicals through Heterogeneous Catalysis; VCH-Wiley: Weinheim, Germany, 2001.

23. Lücke, B.; Narayana, K.V.; Martin, A.; Jähnisch, K. Oxidation and ammoxidation of aromatics. Adv. Synth. Catal. 2004, 346, 1407-1424. [CrossRef]

24. Hatsuda, M.; Seki, M. A practical synthesis of highly functionalized aryl nitriles through cyanation of aryl bromides employing heterogeneous Pd/C: In quest of an industrially viable process. Tetrahedron 2005, 61, 9908-9917. [CrossRef]

25. Nakajima, N.; Saito, M.; Ubukata, M. Activated dimethyl sulfoxide dehydration of amide and its application to one-pot preparation of benzyl-type perfluoroimidates. Tetrahedron 2002, 58, 3561-3577. [CrossRef]

26. Kuo, C.-W.; Zhu, J.-L.; Wu, J.-D.; Chu, C.-M.; Yao, C.-F.; Shia, K.-S. A convenient new procedure for converting primary amides into nitriles. Chem. Commun. 2007, 301-303. [CrossRef] [PubMed]

27. Olah, G.A.; Narang, S.C.; Fung, A.P.; Balaram Gupta, B.G. Synthetic Methods and Reactions; 82. Cyanuric Chloride, a Mild Dehydrating Agent in the Preparation of Nitriles from Amides. Synthesis 1980, 1980, 657-658.

28. Zhou, S.; Junge, K.; Addis, D.; Das, S.; Beller, M. A general and convenient catalytic synthesis of nitriles from amides and silanes. Org. Lett. 2009, 11, 2461-2464. [CrossRef] [PubMed] 
29. Yang, S.H.; Chang, S. Highly efficient and catalytic conversion of aldoximes to nitriles. Org. Lett. 2001, 3, 4209-4211. [CrossRef] [PubMed]

30. Denton, R.M.; An, J.; Lindovska, P.; Lewis, W. Phosphonium salt-catalysed synthesis of nitriles from in situ activated oximes. Tetrahedron 2012, 68, 2899-2905. [CrossRef]

31. Choi, E.; Lee, C.; Na, Y.; Chang, S. $\left[\mathrm{RuCl}_{2} \text { (p-cymene) }\right]_{2}$ on carbon: An efficient, selective, reusable, and environmentally versatile heterogeneous catalyst. Org. Lett. 2002, 4, 2369-2371. [CrossRef] [PubMed]

32. De Luca, L.; Giacomelli, G.; Porcheddu, A. Beckmann rearrangement of oximes under very mild conditions. J. Org. Chem. 2002, 67, 6272-6274. [CrossRef] [PubMed]

33. Baxendale, I.R.; Ley, S.V.; Sneddon, H.F. A clean conversion of aldehydes to nitriles using a solid-supported hydrazine. Synlett 2002, 2002, 775-777. [CrossRef]

34. Chill, S.T.; Mebane, R.C. A facile one-pot conversion of aldehydes into nitriles. Synth. Commun. 2009, 39, 3601-3606. [CrossRef]

35. Srinivas, K.V.N.S.; Reddy, E.B.; Das, B. Highly convenient and efficient one-pot conversions of aldehydes into nitriles and ketones into amides using HY-zeolite. Synlett. 2002, 2002, 0625-0627. [CrossRef]

36. Laulhé, S.; Gori, S.S.; Nantz, M.H. A chemoselective, one-pot transformation of aldehydes to nitriles. J. Org. Chem. 2012, 77, 9334-9337. [CrossRef] [PubMed]

37. Augustine, J.K.; Bombrun, A.; Atta, R.N. A practical and cost-efficient, one-pot conversion of aldehydes into nitriles mediated by "activated DMSO". Synlett 2011, 2011, 2223-2227. [CrossRef]

38. Telvekar, V.N.; Patel, K.N.; Kundaikar, H.S.; Chaudhari, H.K. A novel system for the synthesis of nitriles from aldehydes using aqueous ammonia and sodium dichloroiodate. Tetrahedron Lett. 2008, 49, 2213-2215. [CrossRef]

39. Kelly, C.B.; Lambert, K.M.; Mercadante, M.A.; Ovian, J.M.; Bailey, W.F.; Leadbeater, N.E. Access to nitriles from aldehydes mediated by an oxoammonium salt. Angew. Chem. Int. Ed. 2015, 54, 4241-4245. [CrossRef] [PubMed]

40. Ghorbani-Choghamarani, A.; Zolfigol, M.A.; Hajjami, M.; Sardari, S. Direct synthesis of nitriles from alcohols or aldehydes using $\mathrm{H}_{5} \mathrm{IO}_{6} / \mathrm{KI}$ in aqueous ammonia. Synth. Commun. 2012, 43, 52-58. [CrossRef]

41. Patil, U.B.; Shendage, S.S.; Nagarkar, J.M. One-pot synthesis of nitriles from aldehydes catalyzed by deep eutectic solvent. Synthesis 2013, 45, 3295-3299.

42. Augustine, J.K.; Atta, R.N.; Ramappa, B.K.; Boodappa, C. Propylphosphonic anhydride (T3P $\left.{ }^{\circledR}\right)$ : A remarkably efficient reagent for the one-pot transformation of aromatic, heteroaromatic, and aliphatic aldehydes to nitriles. Synlett 2009, 2009, 3378-3382. [CrossRef]

43. Zhu, J.-L.; Lee, F.-Y.; Wu, J.-D.; Kuo, C.-W.; Shia, K.-S. An efficient new procedure for the one-pot conversion of aldehydes into the corresponding nitriles. Synlett. 2007, 2007, 1317-1319. [CrossRef]

44. Wrobleski, A.; Coombs, T.C.; Huh, C.W.; Li, S.-W.; Aubé, J. The Schmidt reaction. Org. React. 2012, 78, 1-320.

45. McEwen, W.E.; Conrad, W.E.; VanderWerf, C.A. The Schmidt reaction applied to aldehydes and epoxides. J. Am. Chem. Soc. 1952, 74, 1168-1171. [CrossRef]

46. Rokade, B.V.; Prabhu, K.R. Chemoselective Schmidt reaction mediated by triflic acid: Selective synthesis of nitriles from aldehydes. J. Org. Chem. 2012, 77, 5364-5370. [CrossRef] [PubMed]

47. Nandi, G.C.; Laali, K.K. Schmidt reaction in ionic liquids: Highly efficient and selective conversion of aromatic and heteroaromatic aldehydes to nitriles with $\left[\mathrm{BMIM}\left(\mathrm{SO}_{3} \mathrm{H}\right)\right][\mathrm{OTf}]$ as catalyst and $[\mathrm{BMIM}]\left[\mathrm{PF}_{6}\right]$ as solvent. Tetrahedron Lett. 2013, 54, 2177-2179. [CrossRef]

48. Hazarika, N.; Baishya, G. One-pot sequential Schmidt and Ritter reactions for the synthesis of $N$-tert-butyl amides. Eur. J. Org. Chem. 2014, 2014, 5686-5690. [CrossRef]

49. Motiwala, H.F.; Fehl, C.; Li, S.-W.; Hirt, E.; Porubsky, P.; Aubé, J. Overcoming Product Inhibition in Catalysis of the Intramolecular Schmidt Reaction. J. Am. Chem. Soc. 2013, 135, 9000-9009. [CrossRef] [PubMed]

50. Smith, P.A.S. The Schmidt reaction: Experimental conditions and mechanism. J. Am. Chem. Soc. 1948, 70, 320-323. [CrossRef]

51. Bach, R.D.; Wolber, G.J. Theoretical study of the barrier to nitrogen inversion in N-cyano- and $\mathrm{N}$-diazoformimine. Mechanism of the Schmidt reaction. J. Org. Chem. 1982, 47, 239-245. [CrossRef]

52. Ostrovskii, V.A.; Koldobskii, G.I.; Shirokova, N.P.; Gidaspov, B.V. Mechanism of the Schmidt reaction. XVIII. Kinetics of reaction of substituted benzaldehydes with hydrazoic acid in aqueous solutions of sulfuric acid. Zh. Org. Khim. 1977, 13, 339-343. 
53. Ostrovskii, V.A.; Kuznetsov, A.V.; Koldobskii, G.I.; Shirokova, N.P.; Gidaspov, B.V. Mechanism of the Schmidt reaction. XIV. Determination of the ratio of reaction products of substituted benzaldehydes with hydrazoic acid. Zh. Org. Khim. 1975, 11, 1027-1030.

54. Raja, E.K.; Klumpp, D.A. Superelectrophilic chemistry of amino-nitriles and related substrates. Tetrahedron 2011, 67, 4494-4497. [CrossRef] [PubMed]

55. Tsuchiya, D.; Kawagoe, Y.; Moriyama, K.; Togo, H. Direct oxidative conversion of methylarenes into aromatic nitriles. Org. Lett. 2013, 15, 4194-4197. [CrossRef] [PubMed]

56. Yu, L.; Li, H.; Zhang, X.; Ye, J.; Liu, J.; Xu, Q.; Lautens, M. Organoselenium-catalyzed mild dehydration of aldoximes: An unexpected practical method for organonitrile synthesis. Org. Lett. 2014, 16, 1346-1349. [CrossRef] [PubMed]

57. Yu, B.; Guo, C.-X.; Zhong, C.-L.; Diao, Z.-F.; He, L.-N. Metal-free chemoselective oxidation of sulfides by in situ generated Koser's reagent in aqueous media. Tetrahedron Lett. 2014, 55, 1818-1821. [CrossRef]

58. Jang, Y.; Kim, K.T.; Jeon, H.B. Deoxygenation of sulfoxides to sulfides with thionyl chloride and triphenylphosphine: Competition with the Pummerer reaction. J. Org. Chem. 2013, 78, 6328-6331. [CrossRef] [PubMed]

59. Al-Amin, M.; Arai, S.; Hoshiya, N.; Honma, T.; Tamenori, Y.; Sato, T.; Yokoyama, M.; Ishii, A.; Takeuchi, M.; Maruko, T.; et al. Development of second generation gold-supported palladium material with low-leaching and recyclable characteristics in aromatic amination. J. Org. Chem. 2013, 78, 7575-7581. [CrossRef] [PubMed]

60. Yadav, A.K.; Srivastava, V.P.; Yadav, L.D.S. Visible-light-mediated efficient conversion of aldoximes and primary amides into nitriles. RSC Adv. 2014, 4, 4181-4186. [CrossRef]

61. Saha, D.; Saha, A.; Ranu, B.C. Ionic liquid-promoted dehydration of aldoximes: A convenient access to aromatic, heteroaromatic and aliphatic nitriles. Tetrahedron Lett. 2009, 50, 6088-6091. [CrossRef]

62. Dev, D.; Palakurthy, N.B.; Kumar, N.; Mandal, B. An unexpected involvement of ethyl-2-cyano-2-(hydroxyimino) acetate cleaved product in the promotion of the synthesis of nitriles from aldoximes: A mechanistic perception. Tetrahedron Lett. 2013, 54, 4397-4400. [CrossRef]

63. Rudenko, A.P.; Salfetnikova, Y.N.; Vasil'ev, A.V. Oxidation of aromatic compounds. V. Oxidation of substituted benzonitriles and 2,4,6-triaryl-1,3,5-triazines in the HSO3F-PbO2 system. Zh. Org. Khim. 1996, 32, 1499.

64. Luo, Y.; Wen, Q.; Wu, Z.; Jin, J.; Lu, P.; Wang, Y. Copper-mediated cyanation of aryl boronic acids using benzyl cyanide. Tetrahedron 2013, 69, 8400-8404. [CrossRef]

65. Cohen, D.T.; Buchwald, S.L. Mild palladium-catalyzed cyanation of (hetero)aryl halides and triflates in aqueous media. Org. Lett. 2015, 17, 202-205. [CrossRef] [PubMed]

66. Powell, K.J.; Han, L.-C.; Sharma, P.; Moses, J.E. Chemoselective palladium-catalyzed cyanation of alkenyl halides. Org. Lett. 2014, 16, 2158-2161. [CrossRef] [PubMed]

67. Tomioka, T.; Sankranti, R.; Vaughan, T.G.; Maejima, T.; Yanase, T. An $\alpha$-diaminoboryl carbanion assisted stereoselective single-pot preparation of $\alpha, \beta$-disubstituted acrylonitriles. J. Org. Chem. 2011, 76, 8053-8058. [CrossRef] [PubMed]

68. Zhou, W.; Xu, J.; Zhang, L.; Jiao, N. An efficient transformation from benzyl or allyl halides to aryl and alkenyl nitriles. Org. Lett. 2010, 12, 2888-2891. [CrossRef] [PubMed]

69. Geoghegan, K.; Kelleher, S.; Evans, P. An investigation into the one-pot Heck olefination-hydrogenation reaction. J. Org. Chem. 2011, 76, 2187-2194. [CrossRef] [PubMed]

70. Mirjafari, A.; Mohammadpoor-Baltork, I.; Moghadam, M.; Tangestaninejad, S.; Mirkhani, V.; Khosropour, A.R. Microwave-promoted, one-pot conversion of alkoxymethylated protected alcohols into their corresponding nitriles, bromides, and iodides using $[\mathrm{bmim}]\left[\mathrm{InCl}_{4}\right]$ as a green catalyst. Tetrahedron Lett. 2010, 51, 3274-3276. [CrossRef]

Sample Availability: Not avaiable.

(C) 2015 by the authors; licensee MDPI, Basel, Switzerland. This article is an open access article distributed under the terms and conditions of the Creative Commons by Attribution (CC-BY) license (http:/ / creativecommons.org/licenses/by/4.0/). 